\title{
Bilateral frontal epidural abscess
}

\author{
H. Kaptan; K. Çakıroğlu; Ö. Kasımcan and C. Kılıç
}

Department of Neurosurgery, Atatürk Education and Research Hospital. Ankara. Turkey.

\section{Summary}

Description. A 19-year-old male with periorbital painful swelling, headache and vomiting was admitted to our clinic. Because of the diagnosis of sinusitis he had received medical treatment in another center two months before, consisting of antibiotics and analgesics. However as a result of valid persistence of the patients' complaints, brain CT and MR imaging were required; showing bilateral epidural abscess. The patient was operated upon through a coronal incision and bifrontal craniotomy, draining both abscesses and removing their membranes.

Conclusion. Epidural abscess constitute $5-25 \%$ of all the localized intracranial infections. Microorganism colonization may be produced by contiguous infection, hematogenous spread, open cranial trauma or as a consequence of neurosurgical intervention. Sinusitis is one of the most relevant causes of epidural abscesses, mostly in the frontal region. Bilateral occurence is rare. In this paper a case of bilateral epidural abscess is present. Diagnosis criteria and treatment approaches are reviewed.

KEY WORDS: Bilateral. Epidural brain abscess. Sinusitis

\section{Absceso frontal bilateral epidural}

\section{Resumen}

Descripción. Un joven de 19 años ingresó en nuestra clínica con inflamación dolorosa periorbitaria, cefalea y vómitos. Debido al diagnóstico de sinusitis, dos meses antes había recibido un tratamiento con antibióticos y analgésicos en otro centro. Al persistir el dolor se solicitó una TAC y una RM craneal, que mostraron abscesos epidurales bilaterales. El paciente fue intervenida mediante una incisión coronaria y craneotomía bifrontal, con drenaje de los dos abscesos y extirpación

Recibido; 22-08-06. Aceptado: 14-02-07 de sus membranas.

Conclusión. Los abscesos epidurales constituyen el $5-25 \%$ de todas las infecciones intracraneales localizadas. La colonización del microorganismo se puede producir por contigüidad, por vía hematógena, por traumatismo craneal abierto o a consecuencia de una intervención quirúrgica. La sinusitis es una de las causas más relevantes de los abscesos epidurales, sobre todo en la región frontal. La aparición bilateral es rara. En este trabajo, se presenta un caso de absceso epidural bilateral y se revisan los criterios diagnósticos y de tratamiento.

PALABRAS CLAVE: Bilateral. Absceso epidural cerebral. Sinusitis.

\section{Introduction}

Brain abscess, subdural empyema, and epidural abscess are three of the most commonly encountered focal supportive processes of the central nervous system². They may be due to hematogeneous spread cranial trauma or neurosurgical procedures. Frontal lobe abscesses are frequently caused by purulent nasal sinusitis. The most common pathogens are streptococs and gram negative aerob bacteria $^{1,6,9}$. Chronic suppurative otitis media is also a possible origin of intracranial abscesses of which $21.87 \%$ are localized of epidural level. The most common symptoms are headache and fever ${ }^{4}$.

Epidural abscesses constitute 5-25\% of all localized intracranial infections. They are rare pathologies with death risk. Common causes are craniotomies, paranasal sinusitis, mastoid air cell, middle ear infections, cranial osteomyelitis or implants after trauma. Local or diffuse headache are the most common symptoms. In cases associated with frontal sinusitis, periorbital swelling and fever may occur $^{1,3,5,9,18}$. Intracranial complications of frontal sinusitis include epidural, subdural and brain abscesses, meningitis and cavernous sinus trombophlebitis and all can be avoided by appropriate antibiotic treatment. In an autopsy series, $80 \%$ of cases of cranial epidural abscess had evidence of an 


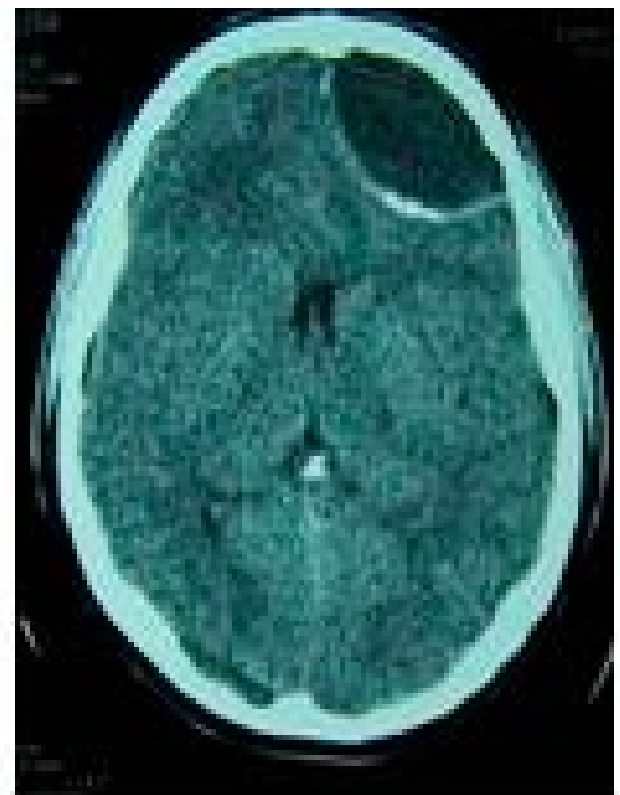

Figure 1. Hypodense image with rim enhancement on left frontal lobe in $C T$

associated subdural abscess ${ }^{1}$.

In laboratory research, high leukocytosis is observed; and blood culture is positive in $10 \%$ of the cases. The use of Cranial Tomography (CT) and the recognition of anaerob microorganisms resulted in a mortality rate decrease from $40 \%$ to $10 \%$. Typically, an epidural abscess is seen on CT as an extra-axial hypodense area with prominent limits ${ }^{1,10}$. MR will better define an intracranial abscess usually hypodense on T1-weighted images and hyperintense on T2weighted images ${ }^{1,5,8,11,18}$.

These life-threatening infections require a combined medical and surgical approach. Surgical treatment with craniotomy drainage, debridement and irrigation of purulent material must be provided. The primer focus must be removed and intravenous antibiotics treatment must be applied for 6-8 weeks. This kind of combined management is usually successful ${ }^{1,4,5,15}$. In epidural abscess related to sinusitis in children, drainage and antibiotics treatment without surgery is an ideal choice ${ }^{7}$.

\section{Case Report}

A 19-year-old male with of periorbital painful swelling, headache and vomiting was admitted to our clinic. Due to nasal fractures, he had been operated twice after a traffic accident occurring 10 years before. In the physical and neurologic examination of the patient there were no abnormal findings except for a slight facial paralysis. Laboratory findings were as follows: no anaerob or aerob organisms were cultured from the abscess. No microorganisms were

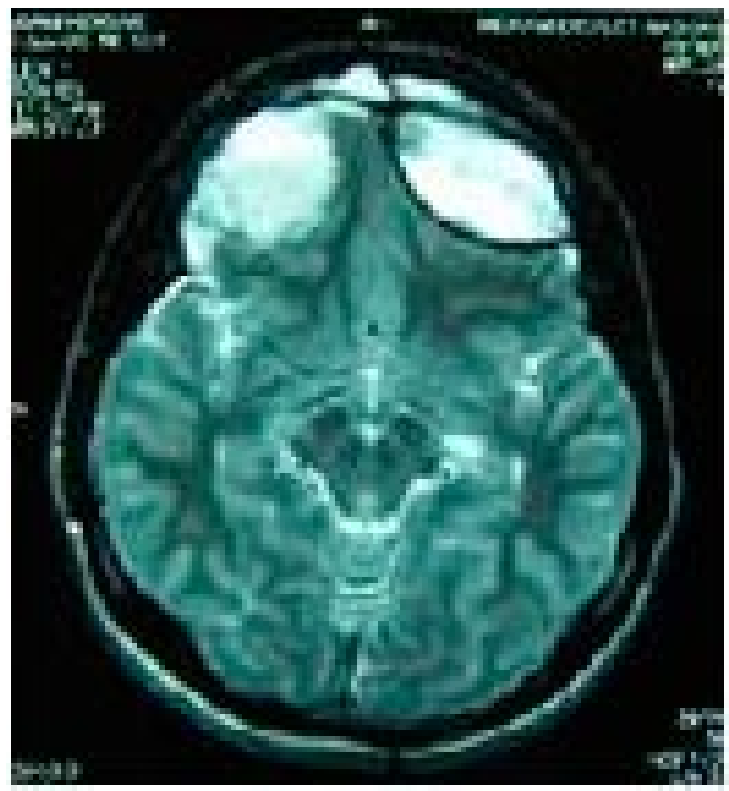

Figure 2. Hyperintense image on bifrontal zon in axial $M R$ scan

observed in gram method.

Because of these complaints, the patient received antibiotics and analgesics in another center two months before admission. The patient had no complaints for 15 days after the antbiotic therapy; however, the first CT and then an MRI were performed due to the repetition of the previous complaints. There was an hypodense area on the CT scan on the left frontal lobe whose limits were clear. MRI T1 and T2 -weighted images showed a hyperintense lesion with partial fluid level. This was similar to epidural hematoma and abscess. Anterior interhemispheric fissure had a minimal deviation to the right.

The patient was operated upon via a coronal incision with bifrontal access to both abscess. The abscesses' membranes were seen and removed and the abscesses were drained. Frontal sinuses were cleaned. Intravenous antibiotic treatment was applied and successfully concluded.

\section{Discussion}

Epidural abscesses may appear as a result of trauma, surgery and sinusitis. Periorbital painful swelling, and headache are typical symptoms of the abscesses after sinusitis. In diabetics, drug or alcohol users and those whose immune systems have been suppressed, it is easier for the abscess to occur. The location of microorganisms may happen by hematogenous spread, contiguity, penetranting cranial trauma or following neurosurgical intervention ${ }^{1,6,8,9,16}$. In our case the above given reasons are involved in the patient's background, and the patient admitted to our clinic 
with typical symptoms. With a careful anamnesis, and consideration of abscess diagnosis, it is possible to by not missing any diagnosis. Despite the decrease in intracranial complications with the developments in surgical technique and antibiotic, sinusitis still carries life-threatening risks. Epidural abscess is one of the most common intracranial complications of sinusitis ${ }^{12,17}$. Even though it is said that high leukocytosis is seen in laboratory examination, the absences of leukocytosis in our case could be due to he was under antibiotic treatment for sinusitis.

Though blood culture is positive in $10 \%$ of the cases, no organisms were cultured from the abscesses in our case. Bilateral frontal abscess was not diagnosed in the first CT scan; only a hypodense area with rim enhancement on the left was observed. Through craniotomy, drainage, irrigation and debridement of the purulent material were performed. In this condition, primary focus of infection should be removed and intravenuous antibiotic therapy applied. Therapy results are generally positive, following a multidisciplinary approach for 6-8 weeks. In our patient, membranes were removed, abscesses were drainaged and frontal sinuses were cleaned; then intravenuous antibiotics therapy was started, resulting in successfull outcome.

\section{Conclusion}

A correct diagnosis of epidural abscess should be reached based on careful anamnesis, clinical suspicion and efficient diagnostic methods. The possibility of intracranial complications secondary to sinusitis should not be ignored. MR imaging will clarify diagnosis and location of intracranial abscesses, facilitating its surgical treatment. Through a combined medical and surgical approach successful results might be achieved when treating these otherwise life-threatening conditions.

\section{References}

1. Artenstein, A.W., Kim, J.H., Schmicdek, H.H.: Suppurative Intracranial Infections. Schmicdek $\mathrm{HH}$, Sweet WH: Operative Neurosurgical Technigues, W: B: Saunders Company, Fourth Edition, Volume 2, Chapter 128, 2000: 16851693

2. Calfee, D.P., Wispelwey, B.: Brain Abscess, Subdural Empyema, and Intracranial Epidural Abscess. Curr Infect Dis Rep. 1999; 1: 166-171.

3. Coyne, T.J., Kemp, R.J.: Intracranial epidural abscess: a report of three cases. Aust N Z JSurg.1993; 63: 154-157.

4. Fountas, K.N., Duwayri, Y., Kapsalaki, E., Dimopoulos, V.G., Johnston, K.W., Peppard, S.B., Robinson, J.S.: Epidural intracranial abscess as a complication of frontal sinusitis: case report and review of the literature. South Med J. 2004; 97: 279-282.
2008; 19: 55-57

5. Gormley, W.R., Busto, R., Saravolatz, L.D. , Rosenblum, M.L.: Cranial Epidural Abscess. En Youmans R (Ed) Neurosurgical Surgery. Fourth Edition. Vol. 5, Ch 148 W.B. Saunders Company. 1997 ( CD Edition )

6. Greenberg, M.S.: Hand Book Neurosurgery, Third Edition, Greenberg Graphics, Lakeland, Florida, 1994 pp: 269-274.

7. Heran, N.S., Steinbok, P., Cochrane, D.D.: Conservative neurosurgical management of intracranial epidural abscesses in children. Neurosurgery. 2003; 53: 893-897; discussion 897898.

8. Lindsay, K.W., Bone, I., Callander, R.: Neurology and Neurosurgery Illustrated, Third Edition, Churcill Livingstone, 1997 pp: 344-347.

9. Maj, B., Kolodziej, W., Latka, D.: Cranial epidural abscesses: a case report. Neurol Neurochir Pol. 2001; 35: 507517.

10. Moonis, G., Granados, A., Simon, S.L.:Epidural hematoma as a complication of sphenoid sinusitis and epidural abscess: a case report and literature review. Clin Imaging. 2002; 26: 382-385.

11. Osborn, A.G.: Infections of the Brain and Its linings, Diagnostic Neuroradiology, Mosby -Year Book, Inc 1994 pp: 673-715.

12. Reader, M.E., Eliachar, I., McIntire, L.D., Hahn, J.: Frontal sinusitis with chronic epidural abscess: a case presentation. Ear Nose Throat J. 1992; 71: 599-603.

13. Rice, D.H., Fishman, S.M., Barton, R.T., Hutcherson, R., Eichel, B.S.: Cranial complications of frontal sinusitis. Am Fam Physician. 1980 Nov; 22: 145-149.

14. Seven, H., Coskun, B.U., Calis, A.B., Sayin, I., Turgut, S.: Intracranial abscesses associated with chronic suppurative otitis media. Eur Arch Otorhinolaryngol. 2005; 262: 847-851.

15. Silverberg, A.L., DiNubile, M.J.: Subdural empyema and cranial epidural abscess. Med Clin North Am. 1985; 69: 361-374.

16. Tsai, Y.D., Chang, W.N., Shen, C.C. eds.: Intracranial suppuration: a clinical comparison of subdural empyemas and epidural abscesses. Surg Neurol. 2003; 59: 191-196.

17. Younis, R.T., Lazar, R.H., Anand, V.K.: Intracranial complications of sinusitis: a 15-year review of 39 cases. Ear Nose Throat J. 2002; 81: 636-638, 640-642, 644.

18. Younis, R.T., Vinod, K., Davidson, B.: The role of computed tomography and magnetic resonance imaging in patients with sinusitis with complications. Laryngoscope. 2002; 112: 224-229.

Kaptan, H.; Çakıroğlu, K.; Kasımcan, Ö.; Kılıç, C.: Bilateral frontal epidural abscess. Neurocirugía 2008; 19: 5557.

Address: Hülagü Kaptan. Reşit Galip Caddesi Hazan Sokak No:5/9. 06700 G.O.P/Ankara. Turkey. 